\title{
Sources and seasonality of atmospheric methanol based on tall tower measurements in the US Upper Midwest
}

\author{
L. Hu ${ }^{1}$, D. B. Millet ${ }^{1}$, M. J. Mohr ${ }^{1}$, K. C. Wells ${ }^{1}$, T. J. Griffis ${ }^{1}$, and D. Helmig ${ }^{2}$ \\ ${ }^{1}$ University of Minnesota, Department of Soil, Water, and Climate, St. Paul, Minnesota, USA \\ ${ }^{2}$ University of Colorado, Institute of Arctic and Alpine Research, Boulder, Colorado, USA \\ Received: 1 June 2011 - Published in Atmos. Chem. Phys. Discuss.: 22 June 2011 \\ Revised: 4 October 2011 - Accepted: 12 October 2011 - Published: 10 November 2011
}

\begin{abstract}
We present over one year (January 2010-February 2011) of continuous atmospheric methanol measurements from the University of Minnesota tall tower Trace Gas Observatory (KCMP tall tower; $244 \mathrm{~m}$ a.g.l.), and interpret the dataset in terms of constraints on regional methanol sources and seasonality. The seasonal cycle of methanol concentrations observed at the KCMP tall tower is generally similar to that simulated by a global 3-D chemical transport model (GEOS-Chem, driven with MEGANv2.0 biogenic emissions) except the seasonal peak occurs $\sim 1$ month earlier in the observations, apparently reflecting a model underestimate of emission rates for younger versus older leaves. Based on a source tracer approach, which we evaluate using GEOS-Chem and with multiple tracers, we estimate that anthropogenic emissions account for approximately $40 \%$ of ambient methanol abundance during winter and $10 \%$ during summer. During daytime in summer, methanol concentrations increase exponentially with temperature, reflecting the temperature sensitivity of the biogenic source, and the observed temperature dependence is statistically consistent with that in the model. Nevertheless, summertime concentrations are underestimated by on average $35 \%$ in the model for this region. The seasonal importance of methanol as a source of formaldehyde ( $\mathrm{HCHO}$ ) and carbon monoxide (CO) is highest in spring through early summer, when biogenic methanol emissions are high but isoprene emissions are still relatively low. During that time observed methanol concentrations account for on average $20 \%$ of the total $\mathrm{CO}$ and $\mathrm{HCHO}$ production rates as simulated by GEOS-Chem, compared to $12 \%$ later in the summer and $12 \%$ on an annual
\end{abstract}

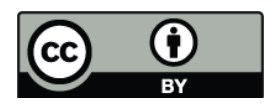

Correspondence to: D. B. Millet (dbm@umn.edu) average basis. The biased seasonality in the model means that the photochemical role for methanol early in the growing season is presently underestimated.

\section{Introduction}

Methanol $\left(\mathrm{CH}_{3} \mathrm{OH}\right)$ is one of the most abundant nonmethane organic gases in the atmosphere, with concentrations ranging from hundreds of parts per trillion (pptv) in the remote troposphere to tens of parts per billion (ppbv) near surface sources (Singh et al., 1995, 2004; Karl et al., 2003; Millet et al., 2004; Schade and Goldstein, 2006; Jordan et al., 2009). It affects background and boundary layer photochemistry, and is an important source of carbon monoxide (CO) and formaldehyde (HCHO) (Riemer et al., 1998; Tie et al., 2003; Millet et al., 2006; Duncan et al., 2007; Choi et al., 2010). Here we present over one full year of methanol concentration measurements from a tall tower observatory in the US Upper Midwest, and interpret the data in terms of the information they provide on seasonal methanol sources and natural versus anthropogenic contributions.

Estimates of the global methanol source range from 75 to $350 \mathrm{Tg} \mathrm{yr}^{-1}$ (Singh et al., 2000, 2004; Galbally and Kirstine, 2002; Tie et al., 2003; Jacob et al., 2005; Millet et al., 2008; Stavrakou et al., 2011), with the largest fluxes from terrestrial plant growth (MacDonald and Fall, 1993; Fall and Benson, 1996; Singh et al., 2000; Karl et al., 2003; Harley et al., 2007; Folkers et al., 2008; Stavrakou et al., 2011). Other methanol sources include emissions from decaying plant matter (Warneke et al., 1999), biomass and biofuel burning (Holzinger et al., 1999; Andreae and Merlet, 2001), urban and industrial activities (de Gouw et al., 2005),

Published by Copernicus Publications on behalf of the European Geosciences Union. 
and atmospheric production (mostly from methane oxidation) (Madronich and Calvert, 1990; Tyndall et al., 2001). The marine biosphere appears to be a large gross source but an even larger gross sink of atmospheric methanol, so that overall it acts as a net sink (Singh et al., 1995; Heikes et al., 2002; Williams et al., 2004; Millet et al., 2008; Stavrakou et al., 2011). Gas-phase oxidation by $\mathrm{OH}$ is the other major methanol sink, with deposition playing a smaller but still significant role (Atkinson et al., 2006; Karl et al., 2010). The overall atmospheric life time for methanol is an estimated 512 days (Heikes et al., 2002; Tie et al., 2003; Singh et al., 2004; Stavrakou et al., 2011).

The atmospheric methanol budget includes substantial uncertainties, most notably in terms of the magnitude and distribution of biogenic emissions, which are large but remain poorly constrained. This in part reflects the scarcity of longterm measurements to constrain methanol emission fluxes and their seasonal variability.

In this paper we report atmospheric methanol measurements made using a proton transfer reaction mass spectrometer (PTR-MS) over one year (January 2010-February 2011) at the University of Minnesota tall tower Trace Gas Observatory (KCMP tall tower), a $244 \mathrm{~m}$ AmeriFlux tall tower in the US Upper Midwest (Fig. 1). Measurements are made at a sampling height of $185 \mathrm{~m}$ above ground level, providing a high-resolution signal with regional-scale footprint. The tower is located near the intersection of the major North American ecosystems (eastern deciduous forest, northern coniferous forest, agriculture, and western prairie), and is at times downwind of the Twin Cities metropolitan area (2010 population: $3.3 \mathrm{M}$ ), thus affording information on emissions of methanol and other reactive gases from some of the most important US landscapes as well as from anthropogenic sources. We apply the tall tower methanol observations with a suite of other chemical measurements, and in combination with a global 3-D chemical transport model (GEOS-Chem), to better understand seasonal methanol sources, natural versus anthropogenic contributions, and the resulting impact on atmospheric formaldehyde and CO.

\section{Methods}

\subsection{Field site description}

The University of Minnesota tall tower Trace Gas Observatory is a Minnesota Public Radio communications tower (KCMP $89.3 \mathrm{FM}, 44.689^{\circ} \mathrm{N}, 93.073^{\circ} \mathrm{W} ; 244 \mathrm{~m}$ height, $534 \mathrm{~m}$ above sea level), located approximately $25 \mathrm{~km}$ south of Minneapolis-St. Paul, MN, US (Fig. 1). Land cover within a $50 \mathrm{~km}$ radius of the tall tower consists of approximately $26 \%$ crops, $18 \%$ grassland, $18 \%$ woodland, $27 \%$ developed land, $6 \%$ wetland, and $5 \%$ water (Corcoran, 2009). May through October is the freeze-free growing season near the site with a $30 \mathrm{yr}$ normal (arithmetic mean) temperature of

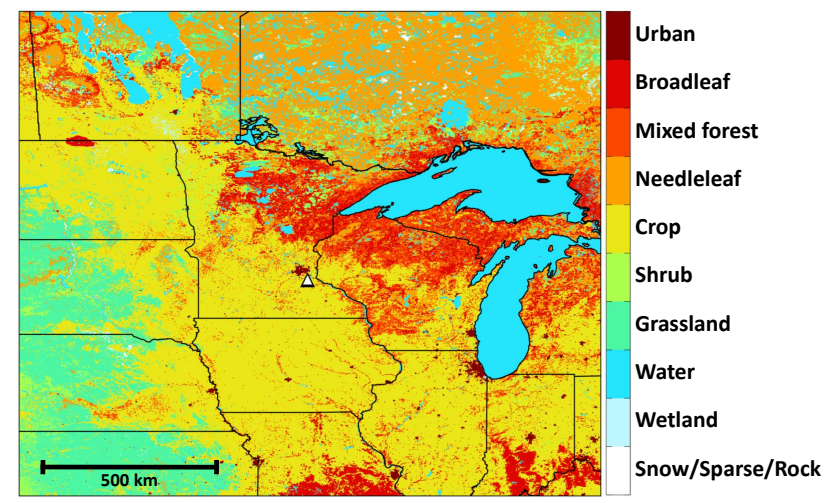

Fig. 1. The KCMP tall tower (white triangle) in Rosemount, $\mathrm{MN}$ is located in the US Upper Midwest near the intersection of the main North American ecosystems. The tower is approximately $25 \mathrm{~km}$ south of the Minneapolis-St. Paul metropolitan area.

$16.6^{\circ} \mathrm{C}\left(\min 11.2^{\circ} \mathrm{C}\right.$, $\left.\max 23.6^{\circ} \mathrm{C}\right)$. The 30 yr normal annual precipitation is $88 \mathrm{~cm}$, about $70 \%$ of which occurs between May and October each year (Corcoran, 2009). Winter is cold (November to January $30 \mathrm{yr}$ mean $-8.2^{\circ} \mathrm{C}$, $\min -12.2^{\circ} \mathrm{C}$, $\max -3.3^{\circ} \mathrm{C}$ ) and the snow cover period can span November to March (Corcoran, 2009; NOAA-MRCC, 2011).

The tower was instrumented with a variety of micrometeorological instruments in April 2007, and is part of the AmeriFlux network (Sitename KCMP tall tower) (Griffis et al., 2010). A three-dimensional sonic anemometer-thermometer (CSAT3, Campbell Scientific Inc., USA) installed near the air sample inlet measures the three components of wind speed and temperature at $10 \mathrm{~Hz}$ for eddy flux measurements of $\mathrm{CO}_{2}, \mathrm{H}_{2} \mathrm{O}$, and sensible heat. A detailed description of meteorological measurements at the site is given by Griffis et al. (2010).

Figure 2 shows the seasonal wind speed and direction observed during 2010 at the KCMP tall tower. Mean wind speeds for each season ranged between 5.5 and $7.5 \mathrm{~m} \mathrm{~s}^{-1}$. Winds during spring were most commonly from south to southeast, while in the summer southerly and north-westerly winds were most frequent. In the autumn and winter, winds were predominantly from the northwest. The footprint sampled by the KCMP tall tower therefore varies through the year, due to these shifting wind patterns (as well as seasonal changes in boundary layer mixing and photochemical lifetimes).

\subsection{Volatile organic compound (VOC) measurements}

We measure methanol and an ensemble of other VOCs (including isoprene and its first-generation oxidation products methyl vinyl ketone and methacrolein; acetone; acetonitrile; and C6-C9 aromatics) at the KCMP tall tower using PTR-MS (HS-PTR-MS, Ionicon Analytik, Austria). In this technique, air flows continuously through a drift tube reaction chamber containing $\mathrm{H}_{3} \mathrm{O}^{+}$ions produced by hollow 


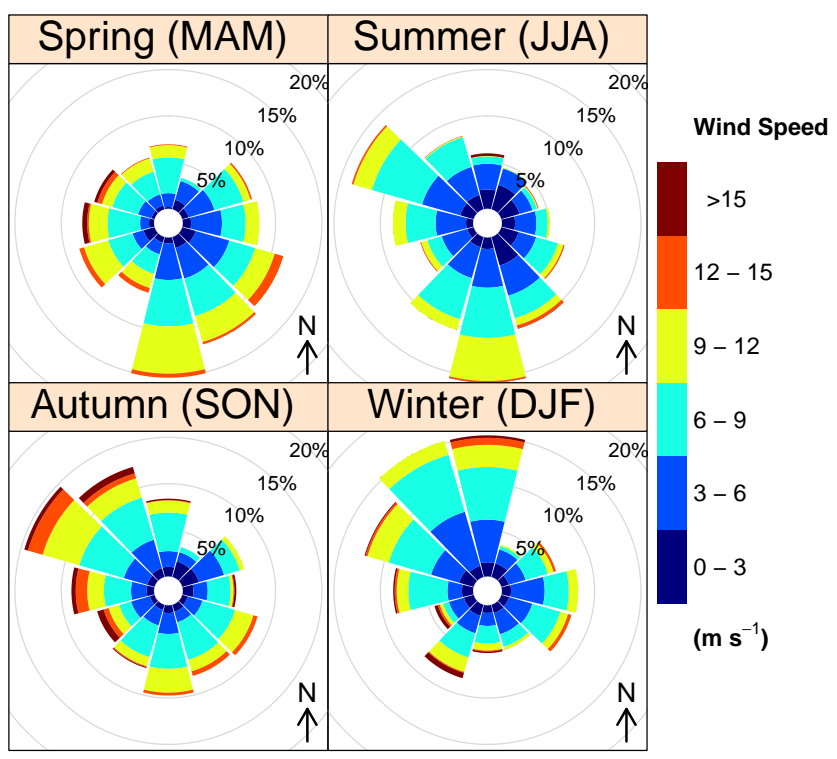

Fig. 2. Wind rose plots showing wind speed as a function of direction during 2010 at the KCMP tall tower. MAM: March, April, May; JJA: June, July, August; SON: September, October, November; DJF: December, January, February.

cathode discharge. VOCs with a proton affinity higher than that of water $\left(>165.2 \mathrm{kcal} \mathrm{mol}^{-1}\right)$ are ionized via protontransfer reaction, and subsequently separated and detected by a quadrupole mass spectrometer with a secondary electron multiplier (Inficon, Liechtenstein) (Lindinger et al., 1998; de Gouw and Warneke, 2007).

The PTR-MS is maintained in an air-conditioned communications building at the base of the tower and was deployed to the site in July 2009. All sampling surfaces are composed of Perfluoroalkoxy (PFA) Teflon tubing to minimize VOC adsorption during measurement (de Gouw and Warneke, 2007; Schnitzhofer et al., 2009) and kept at ambient temperature, except the final $\sim 1 \mathrm{~m}$ of the inlet line, which is passivated stainless steel (SilcoSteel, Restek Corp., USA) heated to $60^{\circ} \mathrm{C}$. A continuous $0.95 \mathrm{~cm} \times 1.27 \mathrm{~cm}$ (I.D. $\times$ O.D. $)$ sampling line (PFA, Jensen Inert Products, USA) extends from there up the tower to the inlet $185 \mathrm{~m}$ above ground, with an inline filter (90 mm PFA filter holder; 30-60 $\mu \mathrm{m}$ PTFE filter membrane, Savillex Corp., USA) installed to remove coarse particulates. A sampling pump pulls air down from the inlet at $\sim 12$ standard $1 \mathrm{~m}^{-1}$, with the line pressure maintained at $\sim 900 \mathrm{hPa}$. The resulting residence time for air in the line is approximately $2 \mathrm{~min}$ under normal sampling conditions. We performed a series of tests to thoroughly investigate any potential VOC wall loss or interference in the $185 \mathrm{~m}$ PFA inlet line. Laboratory experiments showed no detectable effect from the PFA inlet line for any of the reported compounds, consistent with results from another recent study (Schnitzhofer et al., 2009).
During measurement, the PTR-MS steps continuously through a series of 15 protonated VOC masses (including $\mathrm{m} / \mathrm{z} 33$ for methanol), with 2-20 s dwell time on each. Additional masses are monitored for diagnostic purposes at $200 \mathrm{~ms}$ dwell time each (e.g., $\mathrm{H}_{3} \mathrm{O}^{+}, \mathrm{H}_{3} \mathrm{O}^{+}\left(\mathrm{H}_{2} \mathrm{O}\right)$ ), for a total measurement cycle of $26 \mathrm{~s}$ (October 2009 to July 2010) or $170 \mathrm{~s}$ (after August 2010). Drift tube pressure is maintained at 2.0 to $2.3 \mathrm{mbar}$, voltage at $600 \mathrm{~V}$, and temperature at $60^{\circ} \mathrm{C}$.

For all species there is a nonzero background signal because of impurities in the system and/or the presence of unwanted ions from the ion source (de Gouw et al., 2003), so regular background checks under ambient humidity are performed every $2-5 \mathrm{~h}$. Background signals are monitored for 5-10 measurement cycles by passing ambient air flow through a $0.95 \mathrm{~cm} \times 1.27 \mathrm{~cm}$ (I.D. $\times$ O.D.) stainless steel tube filled with platinum bead catalyst $(3 \mathrm{~mm}$ in diameter; Shimadzu Corp., Japan) and heated to $450^{\circ} \mathrm{C}$. After subtracting the interpolated background signals, the raw data are post-processed following de Gouw et al. (2003) to account for humidity effects.

The PTR-MS is calibrated by dynamic dilution of multicomponent standards (AiR Environmental Inc., USA; stated accuracy $\pm 5 \%$ ) into zero air (generated as above). The standard cylinders were originally filled December 2008 and were re-analyzed in May 2011. VOC concentrations in the standards range from tens to hundreds of ppbv depending on the compound (202 ppbv for methanol). Calibration curves were performed automatically every $23 \mathrm{~h}$ through August 2010; this was subsequently decreased to $47 \mathrm{~h}$ because of the observed instrument stability. Under most conditions, the $R^{2}$ values for 6-point calibration curves are $>0.995$ for reported compounds, with the relative standard deviation of residuals $<7 \%$. Detection limits, defined as $3 \times$ the precision, are $\sim 220 \mathrm{pptv}$ for methanol ( $5 \mathrm{~s}$ dwell time), $\sim 18 \mathrm{pptv}$ for benzene ( $10 \mathrm{~s}$ dwell time), and $\sim 30 \mathrm{pptv}$ for toluene (10 s dwell time). Typical sensitivities during calibration are $\sim 10.9 \mathrm{ncps} \mathrm{ppbv}^{-1}$ for methanol, $\sim 10.2 \mathrm{ncps} \mathrm{ppbv}^{-1}$ for benzene, and $\sim 13.2 \mathrm{ncps} \mathrm{ppbv}^{-1}$ for toluene for a drift tube pressure of $2.2 \mathrm{mbar}$ and a drift tube voltage of $600 \mathrm{~V}$. The overall uncertainty of measurement for methanol, based on quadrature addition of the individual error sources (flow controllers, standard accuracy, calibration fit, standard error of the $30 \mathrm{~min}$ averages, etc.), is estimated at $10 \%$ on average (and in nearly all cases $<20 \%$ ).

All analyses presented here were performed using the open-source tools R (www.r-project.org) and openair (www. openair-project.org).

\subsection{CO measurements}

We apply concurrent $\mathrm{CO}$ measurements at the KCMP tall tower in our interpretation of the methanol data. $\mathrm{CO}\left(\right.$ and $\left.\mathrm{H}_{2}\right)$ are measured by gas chromatography (GC) with a reducing compound photometer (Peak Performer 1; Peak Laboratories LLC., USA). $\mathrm{CO}$ and $\mathrm{H}_{2}$ eluting from the GC column 
(Unibeads 1S and MS 13X) pass directly into a heated mercuric oxide bed $\left(265^{\circ} \mathrm{C}\right)$. During the process, mercury vapour is liberated and subsequently measured via UV light absorption in the photometer cell. Compressed medical grade air is used as carrier gas. Multi-point calibrations are carried out daily by dynamic dilution of a ppmv-level standard (Scott Specialty Gases, USA; stated accuracy $\pm 2 \%$ ) into zero air generated by passing ambient air through a Sofnocat catalyst (Molecular Products Inc., USA) bed heated to $60^{\circ} \mathrm{C}$. Under normal conditions, the $R^{2}$ values for 6-point calibration curves are $>0.999$ for both $\mathrm{CO}$ and $\mathrm{H}_{2}$, with the relative standard deviation of residuals $<3 \%$. The detection limits for $\mathrm{CO}$ and $\mathrm{H}_{2}$ are 300 and 800 pptv respectively for 3 min measurements.

\subsection{GEOS-Chem chemical transport model}

We use the GEOS-Chem 3-D model of atmospheric chemistry (Bey et al., 2001) as a tool to interpret the tall tower observations in terms of constraints on methanol source types. GEOS-Chem (v8, http://www.geos-chem.org) is a global Eulerian chemical transport model driven by assimilated meteorological observations from the NASA Goddard Earth Observing System (GEOS-5). The meteorological fields have $0.5^{\circ} \times 0.667^{\circ}$ horizontal resolution and 72 vertical layers. For our work here we reduce the spatial resolution to $2^{\circ} \times 2.5^{\circ}$ and 47 layers, of which 14 are below $2 \mathrm{~km}$ altitude, and use a $15 \mathrm{~min}$ transport timestep. For methanol, we apply here the simulation implemented in GEOS-Chem by Millet et al. (2008), with updates outlined below, while for $\mathrm{CO}$ and other tracers we apply the full-chemistry simulation described in Millet et al. (2010).

Biogenic emissions of methanol and other VOCs are computed online in GEOS-Chem using the Model of Emissions of Gases and Aerosols from Nature (MEGANv2.0; Guenther et al., 2006). This is change over the earlier work by Millet et al. (2008), which used a simple net primary productivity (NPP) based parameterization for estimating emission. Here, fluxes are estimated for each model grid square as a sum of contributions from four plant functional types (PFTs: broadleaf trees, needleleaf trees, shrubs, and herbaceous plants [crops + grasslands]):

$$
E=\gamma \sum_{i=1}^{4} \varepsilon_{i} \chi_{i}
$$

where $\varepsilon_{i}$ is the canopy emission factor for PFT $i$ with fractional coverage $\chi_{i}$. Here we use $\varepsilon_{i}=800 \mu \mathrm{g} \mathrm{m}^{-2} \mathrm{~h}^{-1}$ for the four PFTs. The overall activity factor $\gamma$ is calculated from a set of individual activity factors accounting for the effects of temperature, photosynthetic photon flux density (PPFD), leaf age, and leaf area index (LAI) on emissions. Activity factors for LAI, PPFD and leaf age are computed as described by Stavrakou et al. (2011) and Guenther et al. (2006), but using a light-dependent fraction of 0.75 and relative emission rates of 3.0, 2.6, 0.85, and 1.0 for new, young, mature, and old leaves. Leaf age fractions are parameterized based on monthly changes in leaf area index as described by Guenther et al. (2006). The higher emission rate for old relative to mature leaves represents the methanol flux from dead and decaying foliage (Warneke et al., 1999). The temperature dependence of methanol emission is modelled using an exponential function,

$\gamma_{T}=\exp [\beta(T-303)]$

with $\beta=0.08$ and $T$ the surface air temperature $(\mathrm{K})$. The global annual flux of methanol from terrestrial plants for this simulation is $95 \mathrm{Tg}$ in 2010 . This is significantly lower than the base-case simulation presented by Millet et al. (2008) using the NPP-based parameterization of biogenic emissions $\left(145 \mathrm{Tg}^{-1}\right)$, and comparable to their optimized estimates based on a reduced biogenic source $\left(72-89 \mathrm{Tg}^{-1}\right)$.

Anthropogenic emissions over the US are from the US EPA NEI-99 (EPA, 1999), updated by Hudman et al. (2007; 2008) to account for recent $\mathrm{CO}$ and $\mathrm{NO}_{\mathrm{x}}$ emission reductions. The anthropogenic methanol flux is estimated based on a methanol:CO molar emission ratio of 0.012 (Goldan et al., 1995; de Gouw et al, 2005; Millet et al., 2005; Warneke et al., 2007). Methanol emissions from fires are from the Global Fire Emissions Database version 2 (GFEDv2, van der Werf et al., 2006) for the year 2008 (the most recent year for which these emissions are available) and measured species:species pyrogenic emission ratios (Andreae and Merlet, 2001; Andreae, unpublished data, 2006). Other methanol sources (biofuel burning, photochemical production, gross ocean emission) and sinks (oxidation by $\mathrm{OH}$, gross ocean uptake) are implemented as described in our earlier work (Millet et al., 2008).

GEOS-Chem is not necessarily expected to fully resolve the fine-scale concentration fluctuations observed at the KCMP tall tower due to the $2^{\circ} \times 2.5^{\circ}$ model resolution. However, as we will show it does provide a useful way to leverage the observations in testing some basic assumptions in terms of how methanol sources are represented in current models.

\section{Results and discussion}

\subsection{Seasonality of methanol abundance and emissions in the US Upper Midwest}

Figure 3 shows hourly mean methanol mixing ratios observed from January 2010 through February 2011 at the KCMP tall tower. Also shown are concurrent measurements of benzene, toluene, $\mathrm{CO}$, and air temperature. For all compounds statistical outliers ( $>0.98$ quantile for each month) have been removed prior to plotting. Table 1 shows the corresponding seasonal statistics for methanol along with data 
from related sites where measurements covered multiple seasons.

Methanol is the most abundant VOC measured at the KCMP tall tower, with a 2010 annual mean mixing ratio of $3.8 \mathrm{ppbv}$ (median $3.0 \mathrm{ppbv}$ ). The highest seasonal mixing ratios of methanol are observed during summer, reflecting biogenic emissions in the warm season. Lowest concentrations are seen during winter; spring and autumn show intermediate levels of similar magnitude (Table 1). This seasonality is broadly consistent with the few other in-situ observations spanning a full annual cycle (Table 1; Schade and Goldstein, 2006; Jordan et al., 2009; Lappalainen et al., 2009).

We also see in Fig. 3 some wintertime events with strongly elevated concentrations of methanol (as well as of benzene, toluene, and $\mathrm{CO}$ ). These reflect local anthropogenic emissions within the shallow wintertime mixed layer, transported from the Twin Cities by northwesterly winds (predominant at that time of year).

Prior methanol observations in the US Midwest are sparse (Table 1). They include urban measurements in Pittsburgh PA (on average $\sim 1.6-2.4$ times higher than observed at the KCMP tall tower) (Millet et al., 2005) and measurements over a mixed hardwood forest in northern Michigan $(\sim 1.2-$ 2.0 times higher than KCMP) (Karl et al., 2003). Table 1 shows that the methanol concentrations at the KCMP tall tower are generally in the range observed at rural sites elsewhere in the US and abroad.

Figure 3 also shows the methanol concentrations simulated by GEOS-Chem at the KCMP tall tower (red). The model consistently underestimates the observed concentrations year-round, with $\sim 35 \%$ low bias during summer. This can be compared to other recent findings by Millet et al. (2008) and Stavrakou et al. (2011). Using an NPPbased parameterization of biogenic emissions, and after scaling down this biogenic flux to account for a source overestimate, Millet et al. (2008) found that their simulation still had a slight high bias in the eastern US and a low bias in the west. Likewise, on the basis of satellite observations from the IASI sensor, Stavrakou et al. (2011) found that MEGAN overpredicts emissions in the eastern US while underpredicting in the west. More work is needed to better quantify methanol emission rates in different ecosystems and regions, but the observations reported here suggest a source underestimate for the US Upper Midwest.

The seasonality of methanol concentrations as seen in Fig. 3 is clearly distinct from that of $\mathrm{CO}$, benzene, and toluene, which are predominantly emitted from anthropogenic sources ( $\mathrm{CO}$ is also produced in the atmosphere from VOC oxidation, as we discuss later). Mixing ratios for these species are low in the summer and peak during winter, reflecting the seasonal change in $\mathrm{OH}$ radical concentrations. Below (Sect. 3.2) we will use these anthropogenic compounds as tracers to evaluate the relative importance of biogenic versus anthropogenic methanol sources for the region sampled by the KCMP tall tower.
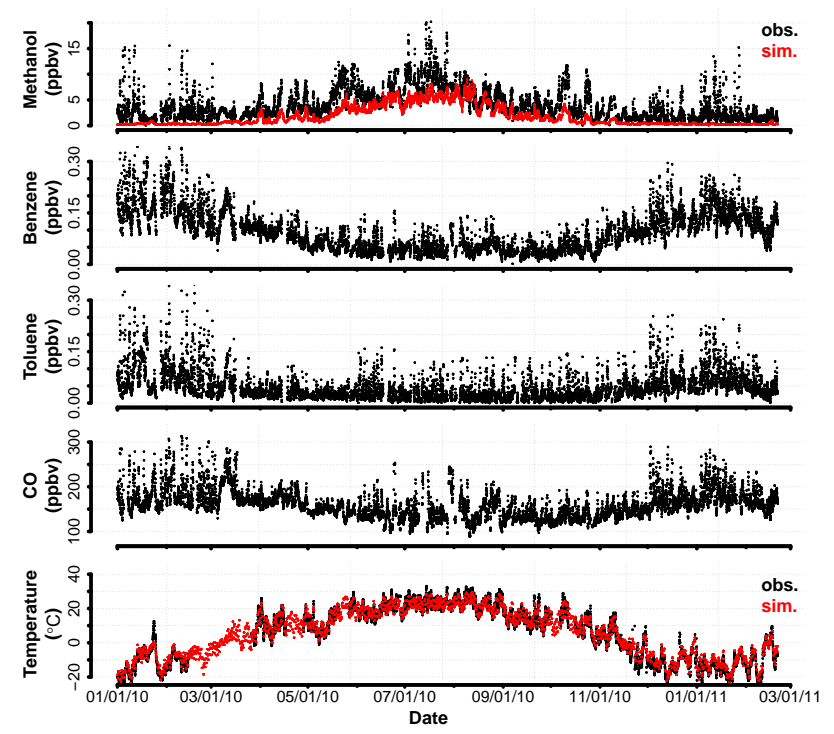

Fig. 3. Annual cycle in methanol, benzene, toluene, CO and air temperature observed at the KCMP tall tower from January 2010 through February 2011 (black). Methanol concentrations simulated by GEOS-Chem are shown in red, as are the assimilated temperatures used to drive the model. All data points are $1 \mathrm{~h}$ means. For all compounds statistical outliers ( $>0.98$ quantile for each month) have been removed prior to plotting.

Current understanding of the seasonality of methanol emissions is based on the premise that pectin biosynthesis during plant and leaf growth is a major source of atmospheric methanol, resulting in higher emissions from new and young leaves in spring and early summer as compared to mature and old leaves during later summer and autumn (MacDonald and Fall, 1993; Fall and Benson, 1996; Galbally and Kirstine, 2002; Fall, 2003; Karl et al., 2003). Long-term measurements from the KCMP tall tower, with its source footprint influenced by multiple PFTs, provide an opportunity to test how well this seasonal dependence is represented in current models.

Figure 4 shows the normalized seasonality in methanol abundance observed at the KCMP tall tower (black) compared to that simulated by GEOS-Chem (red). The simulated seasonality is generally similar to the observations, peaking in summer and with a winter minimum. However, the modeled seasonal amplitude is stronger than observed (simulated summer:winter ratio of 3 versus an observed value of 2). As we discuss later, this in part reflects a model underestimate of the anthropogenic methanol source for this region.

As Fig. 4 shows, the onset of biogenic methanol emissions is well-captured by the model, with measured and simulated concentrations rising in parallel during mid-April and May, and in concert with increasing regional leaf area. However, the seasonal peak in the model is phase-shifted relative to the observations, occurring substantially later in the summer (second week of August versus mid-July in the observations). 
Table 1. Seasonality of atmospheric methanol abundance (ppbv) observed at the KCMP tall tower in the US Upper Midwest and comparison with other sites.

\begin{tabular}{|c|c|c|c|c|c|c|c|}
\hline & & spring $^{1}$ & summer $^{1}$ & autumn $^{1}$ & winter $^{1}$ & land cover & $\begin{array}{c}\text { measurement } \\
\text { height }\end{array}$ \\
\hline \multirow{3}{*}{$\begin{array}{c}\text { KCMP tall } \\
\text { tower, MN, } \\
\text { US (2010-2011; } \\
\text { this study) }\end{array}$} & mean & 4.0 & 7.0 & 3.2 & 2.1 & \multirow{3}{*}{$\operatorname{mix}$} & \multirow{3}{*}{$185 \mathrm{~m}$} \\
\hline & median & 3.2 & 6.6 & 2.8 & 1.6 & & \\
\hline & $\begin{array}{l}10^{t h}-90^{t h} \\
\text { percentiles }\end{array}$ & $1.8-7.6$ & $3.9-10.3$ & $1.1-5.9$ & $0.8-3.8$ & & \\
\hline $\begin{array}{l}\text { Pittsburgh, } \\
\text { PA, US } \\
(2002)^{2}\end{array}$ & median & & 10.7 & & 3.8 & urban & surface \\
\hline $\begin{array}{c}\text { UMBS, } \\
\text { MI, US } \\
(2001-2002)^{3}\end{array}$ & mean & 8 & 10 & 4 & & $\begin{array}{l}\text { mixed } \\
\text { forest }\end{array}$ & $34 \mathrm{~m}$ \\
\hline $\begin{array}{c}\text { UC Berkeley } \\
\text { BFRS, CA, US } \\
(2000-2001)^{4}\end{array}$ & median & & 10.9 & & 2.0 & needleleaf & $12 \mathrm{~m}$ \\
\hline $\begin{array}{c}\text { Thompson Farm, } \\
\text { NH, US } \\
(2004-2007)^{5}\end{array}$ & median & 1.3 & 2.7 & 1.1 & 1.0 & $\begin{array}{c}\text { crop and } \\
\text { mixed forest }\end{array}$ & $12 \mathrm{~m}$ \\
\hline $\begin{array}{c}\text { Zurich, } \\
\text { Switzerland } \\
(2005-2006)^{6}\end{array}$ & mean & 2.2 & 3.2 & 1.1 & 1.2 & urban & surface \\
\hline $\begin{array}{l}\text { SMEAR-II, } \\
\text { Finland } \\
(2006-2007)^{7}\end{array}$ & $\begin{array}{c}\text { day-time } \\
\text { median }\end{array}$ & $\sim 0.5$ & $\sim 2$ & $\sim 1$ & $\sim 0.4$ & needleleaf & $14 \mathrm{~m}$ \\
\hline
\end{tabular}

\footnotetext{
${ }^{1}$ Seasons here are: spring (March-May), summer (June-August), autumn (September-November), winter (December-February)

2 Pittsburgh, PA, USA; Millet et al. (2005)

${ }^{3}$ University of Michigan Biological Station, MI, USA; Karl et al. (2003)

${ }^{4}$ UC Berkeley Blodgett Forest Research Station, CA, USA; Schade and Goldstein (2006)

5 Thompson Farm, NH, USA; Jordan et al. (2009)

${ }^{6}$ Zurich, Switzerland; Legreid et al. (2007)

7 SMEAR-II, Hyytiälä, Finland; Lappalainen et al. (2009)
}

Later (Sect. 3.3) we assess how errors in the assimilated temperatures used to drive GEOS-Chem and MEGAN affect the model:measurement comparisons, but the temperature bias is small and cannot explain this seasonality offset. It appears likely that MEGAN is underestimating the relative methanol emission rate for younger versus older leaves, at least for this part of North America.

\subsection{Anthropogenic versus biogenic sources of methanol}

In this section we apply the KCMP tall tower measurements to evaluate the year-round importance of anthropogenic methanol emissions in the US Upper Midwest. Globally, anthropogenic methanol emissions are uncertain $\left(2-11 \mathrm{Tg} \mathrm{yr}^{-1}\right)$ and are thought to make up only a small fraction of the total flux (2-5\%; Singh et al., 2000; Galbally and Kirstine, 2002; Heikes et al., 2002; Jacob et al., 2005; Millet et al., 2008; Stavrakou et al., 2011). On a regional scale, and in winter, the contribution from urban and industrial sources can be more substantial.

In winter, methanol concentrations at the KCMP tall tower are well-correlated with $\mathrm{CO}$, benzene, and toluene $(R=0.67$, 0.54 , and 0.65 , respectively during December-February), providing a fingerprint of regional anthropogenic emissions in the absence of any significant biogenic sources (or of photochemical production in the case of $\mathrm{CO}$ ). The corresponding methanol:tracer major axis slopes are $0.034(0.032-0.035)$ $\mathrm{ppbv}_{\mathrm{ppbv}}^{-1}$ for CO, $21.3(20.2-22.4) \mathrm{ppbv} \mathrm{ppbv}^{-1}$ for benzene, and 26.0 (24.2-27.9) $\mathrm{ppbvppv}^{-1}$ for toluene (values in parentheses indicate $95 \%$ confidence intervals, CI). For this analysis we remove data above the 0.8 quantile to ensure a regionally representative signal, and subtract a 7 day running 0.1 quantile to eliminate any influence from changing atmospheric background concentrations. No statistical difference in the slopes is seen for weekdays versus weekends, and no clear enhancements of acetonitrile 


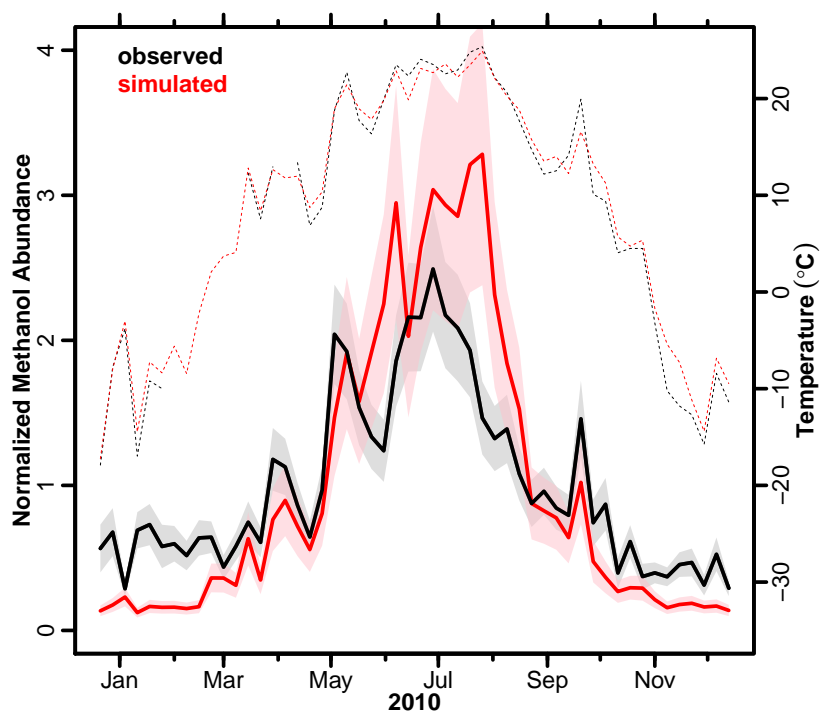

Fig. 4. Seasonality of atmospheric methanol abundance in the US Upper Midwest. Weekly medians (normalized to the annual average) observed at the KCMP tall tower (solid black line) are compared to the corresponding values simulated by GEOS-Chem (solid red line). Shaded areas show the $95 \%$ confidence intervals. Dashed lines show the weekly median air temperatures measured at the site (black) and the assimilated values used to drive GEOS-Chem (red).

(a biomass burning tracer) were observed during winter.We therefore treat the observed methanol:tracer enhancement ratios as regional urban emission ratios, including contributions from fossil fuel combustion, industrial activity, and solvent use.

The observed wintertime methanol:CO slope can be compared to previously reported methanol:CO enhancement ratios which range from 0.004 to $0.056 \mathrm{ppbv} \mathrm{ppbv}^{-1}$ (Goldan et al., 1995; Singh et al., 1995; Salisbury et al., 2003; Jacob et al., 2005; Warneke et al., 2007; and references therein). The wintertime methanol: $\mathrm{CO}$ enhancement ratio observed at the KCMP tall tower is a factor of 2.8 higher than the global emission ratio employed in GEOS-Chem (0.012 ppbv ppbv $^{-1}$; Millet et al., 2008), indicating a significantly larger anthropogenic methanol flux for this area.

We apply here the observed tracer-tracer correlations to diagnose the anthropogenic methanol contribution $f_{\mathrm{ANTH}}$ throughout the year as:

$$
f_{\mathrm{ANTH}}=\frac{E_{\mathrm{X}}[\mathrm{X}]_{t}}{\left[\mathrm{CH}_{3} \mathrm{OH}\right]_{t}}
$$

where $E_{\mathrm{X}}$ is the methanol enhancement ratio relative to tracer X (CO, benzene, or toluene) derived from the wintertime data, $[\mathrm{X}]_{t}$ is the observed enhancement of $\mathrm{X}$ at time $t$, and $\left[\mathrm{CH}_{3} \mathrm{OH}\right]_{t}$ is the observed methanol abundance at time $t$. Potential biases in this method can arise from the assumption of a constant emission ratio, or because of differing atmospheric lifetimes for the compound of interest and the tracer.
The secondary CO source from VOC oxidation (Hudman et al., 2008) can also complicate interpretation. We therefore evaluate the robustness of the approach in two ways. First, we apply it to the $\mathrm{CO}$ and methanol concentrations simulated by GEOS-Chem and compare the result with the actual anthropogenic methanol abundance in the model, which is known. Second, we assess the consistency of the findings using multiple anthropogenic tracers $(\mathrm{CO}$, benzene, and toluene) in the observations. These analyses provide a means of estimating the uncertainty in the results.

Figure 5 (top panel) shows the source tracer approach applied to simulated methanol and $\mathrm{CO}$ concentrations from GEOS-Chem. The anthropogenic fraction $f_{\mathrm{ANTH}}$ estimated using the methanol: $\mathrm{CO}$ correlation agrees well with the actual model value: major axis regression of the calculated versus actual model $f_{\text {ANTH }}$ yields a slope of 0.95 (95\% CI: $0.80-1.09$ ) with $R=0.83$ (Fig. 6). Likewise, applying CO, benzene and toluene as tracers to estimate $f_{\text {ANTH }}$ in the observations gives consistent results to within $\pm 30 \%$ (Fig. 6). Both tests thus provide support for the use of this method in interpreting the observations.

Figure 5 (middle panel) shows the year-round anthropogenic contribution to the observed methanol abundance at the KCMP tall tower estimated on the basis of measured CO (black), benzene (red), and toluene (blue). In all cases we see a pronounced and consistent seasonal cycle, where regional anthropogenic sources account for approximately $10 \%$ of observed levels during summer, and up to $70 \%$ (on average $40 \%$ ) during winter. The seasonality is driven by the changing importance of biogenic emissions, rather than by any strong variation in the absolute anthropogenic flux itself: the bottom panel of Fig. 5 shows that the weekly median anthropogenic contribution is between $0.2-1.5 \mathrm{ppbv}$ year-round. The source tracer approach does not provide a straightforward way to parse the residual, non-anthropogenic methanol abundance: biogenic tracers, such as isoprene, tend to be short-lived, and emissions may not correlate particularly well with those of methanol. In the GEOS-Chem simulation the corresponding non-anthropogenic fraction is almost exclusively biogenic during summer (with nearly $80 \%$ from crops and grasslands), and during winter represents a mixture of transported biogenic emissions, biomass and biofuel burning, and photochemical production.

We repeated this analysis with a filter applied $\left(30^{\circ}<\right.$ wind direction $<300^{\circ}$ ) to exclude air masses transported directly from Minneapolis-St. Paul; this resulted in only minor changes to the calculated anthropogenic component (to approximately $13 \%$ of the total in summer and $44 \%$ in winter).

\subsection{Temperature control on methanol emissions}

Biogenic methanol emissions increase exponentially with temperature (Harley et al., 2007; Folkers et al., 2008). In this section, we use the tall tower measurements during summer, when (as we have shown above) the land biosphere 

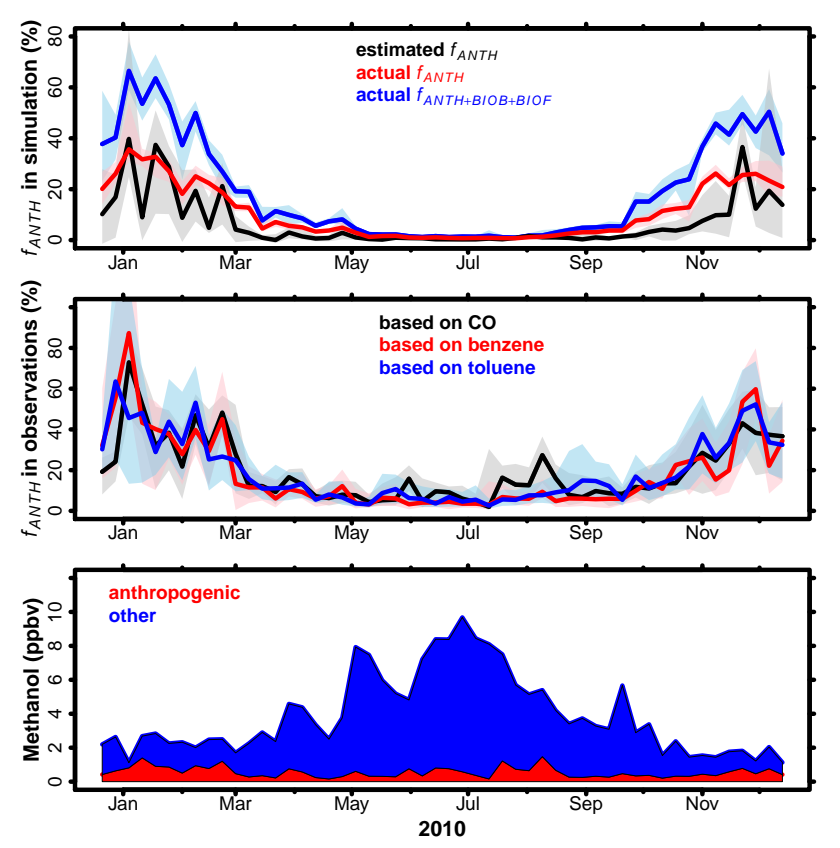

Fig. 5. Top panel: seasonal contribution of anthropogenic sources to simulated methanol abundance in GEOS-Chem. The black line shows the weekly median anthropogenic contribution estimated from the methanol: $\mathrm{CO}$ correlation as a test of the same approach applied to the observations. Also shown are the actual model contributions from anthropogenic emissions (red line) and from anthropogenic emissions + biomass and biofuel burning (blue line). Shaded areas show the interquartile range in each case. Middle panel: seasonal anthropogenic contribution to methanol abundance at the KCMP tall tower estimated using different anthropogenic tracers (black: CO; red: benzene; blue: toluene). The shaded areas represent the interquartile range about the weekly median. Bottom panel: stack plot of seasonal anthropogenic methanol concentrations (red) at the KCMP tall tower estimated using $\mathrm{CO}$ as the anthropogenic tracer (weekly median values). The blue area shows the cumulative contribution to the observed methanol abundance from other sources, including regional and transported biogenic emissions, photochemical production, fires, etc.

is the dominant source, to test the temperature-flux relationship used in present models.

Figure 7 shows daytime summer (June-August, 07:0018:00 LST) methanol concentrations as a function of temperature. A wind direction filter $\left(30^{\circ}<\right.$ wind direction $<$ $300^{\circ}$ ) is applied to exclude urban impacts from MinneapolisSt. Paul. An exponential fit to the observations in Fig. 7 yields a coefficient of 0.087 (95\% CI: 0.082-0.094), in the range of previously published values (0.068-0.094) (Riemer et al., 1998; Schade and Goldstein, 2006; Lappalainen et al., 2009). The observed coefficient is also statistically consistent with the corresponding value from a fit of the simulated methanol abundance to the assimilated temperature used to drive GEOS-Chem (0.083, $95 \%$ CI: 0.078-0.088), and with
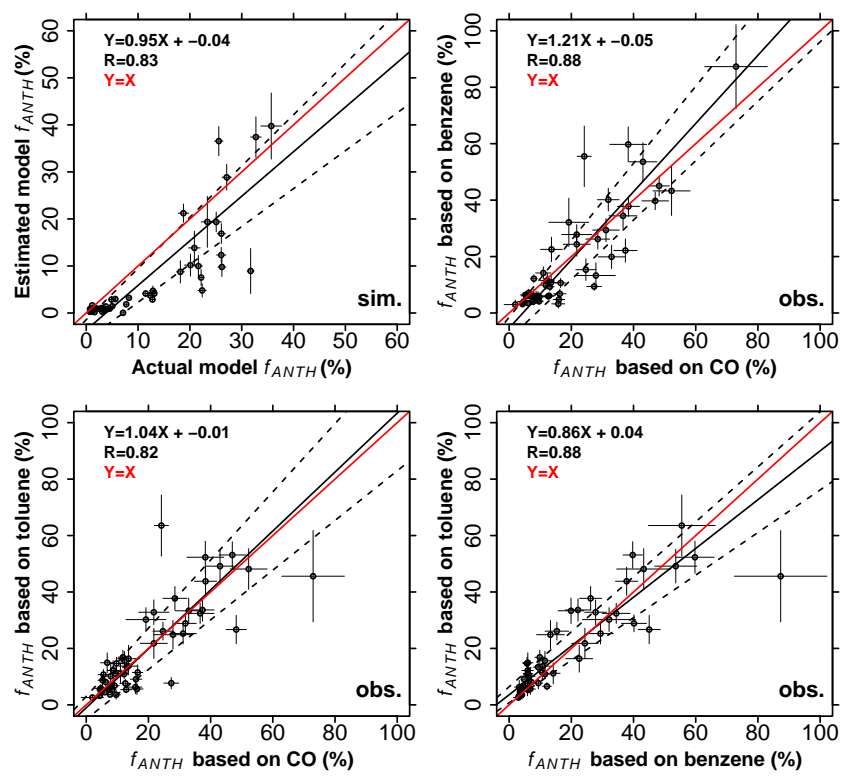

Fig. 6. Top left panel: weekly anthropogenic methanol contribution in the model, estimated using the methanol: CO correlation, compared to the actual model values. The other panels compare the anthropogenic methanol contribution in the observations estimated using the different source tracers ( $\mathrm{CO}$, benzene, and toluene). Black solid lines show the best fit (major axis regression), with regression parameters given inset. Black dashed lines show the $95 \%$ confidence interval for the best fit line. The 1:1 line is shown in red. Error bars show the $95 \%$ confidence interval for each weekly median.

the $\beta$ value used in the emission algorithm (0.08; Eq. 2). We conclude that the model biogenic temperature response is accurate to within the constraints provided by the KCMP tall tower observations.

We analyzed the anthropogenic tracers $\mathrm{CO}$, benzene, and toluene in a similar manner, and found no positive correlation with temperature $(R \leq 0.1)$, so that the strong observed methanol:temperature correlation is mainly providing information relevant to the biogenic source, rather than vertical mixing or evaporative emissions.

The fact that the simulated methanol concentrations are biased low by $\sim 35 \%$ in the summer compared to the observations (Fig. 3) thus suggests that some emission parameters, other than the temperature dependence, are not adequately represented for this region in GEOS-Chem and MEGANv2.0. The GEOS-5 temperatures used in GEOSChem have a slight low bias (on average $-0.9^{\circ} \mathrm{C}$ ) compared to the observations, but we find that correcting this would increase model concentrations by only $\sim 10 \%$, significantly less than the model-measurement mismatch. 


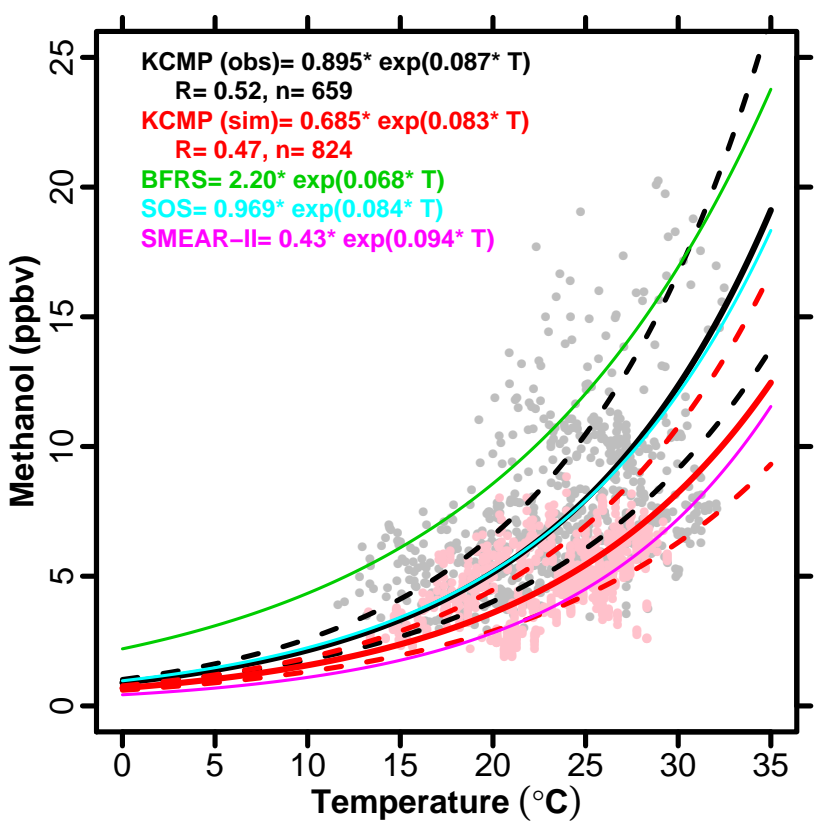

Fig. 7. Methanol concentrations (ppbv) versus temperature $\left({ }^{\circ} \mathrm{C}\right)$. Shown are observed (black) and simulated (red) methanol concentrations at the KCMP tall tower during daytime in summer (JuneAugust; 07:00-18:00 LST). Solid lines (black and red) show an exponential fit (major axis regression) to the observations and model output, with regression parameters given inset and $95 \%$ confidence intervals shown by the dashed lines. Also shown are the corresponding exponential fits derived from previous studies in California US (BFRS, Schade and Goldstein, 2006); Tennessee US (SOS, Riemer et al., 1998); and Hyytiälä Finland (SMEAR-II, Lappalainen et al., 2009).

\subsection{Methanol as a source of $\mathrm{HCHO}$ and $\mathrm{CO}$}

$\mathrm{HCHO}$ and $\mathrm{CO}$ are produced sequentially during the oxidation of methanol by $\mathrm{OH}$ and with essentially quantitative yield. The production rate of $\mathrm{HCHO}\left(P_{\mathrm{HCHO}}\right)$ and $\mathrm{CO}\left(P_{\mathrm{CO}}\right)$ from methanol oxidation is:

$$
P_{\mathrm{CO}} \approx P_{\mathrm{HCHO}}=k_{\mathrm{OH}} Y[\mathrm{OH}]\left[\mathrm{CH}_{3} \mathrm{OH}\right]
$$

with $k_{\mathrm{OH}}$ the rate constant for reaction of methanol with $\mathrm{OH}$ (Atkinson et al., 2006) and $Y$ the HCHO yield (1.0). The production rate of $\mathrm{CO}$ from methanol is essentially equivalent to the production rate of $\mathrm{HCHO}$, since the $\mathrm{HCHO}$ lifetime is $\sim 10$ times shorter than that of methanol (Atkinson et al., 2006), and depositional sinks for HCHO are small (Dufour et al., 2009).

Figure 8 shows the $\mathrm{CO}$ and $\mathrm{HCHO}$ production rates computed from the methanol measurements at the KCMP tall tower. We plot these also as a fraction of the total $\mathrm{CO}$ and HCHO production rates simulated by GEOS-Chem (right panel), to gauge methanol's importance as a source of these two important compounds in the US Upper Midwest $(\mathrm{OH}$ concentrations in Eq. (4) are likewise taken from the model).
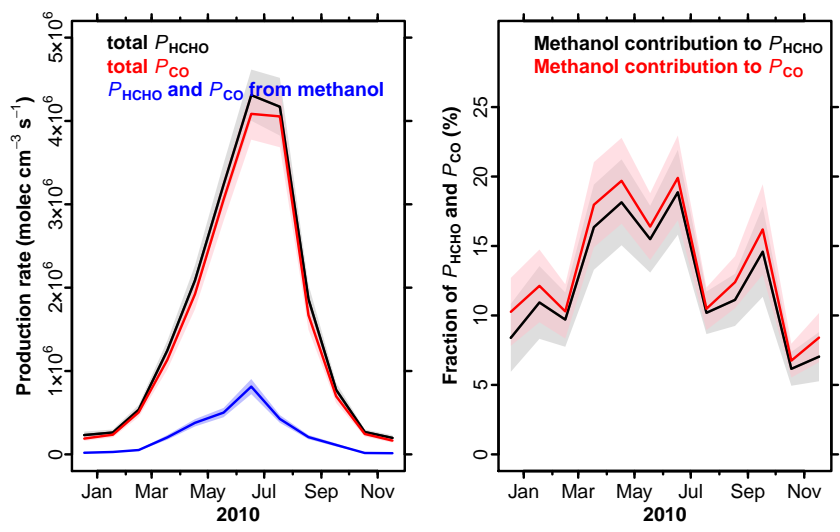

Fig. 8. Monthly mean methanol contribution to the production rates of $\mathrm{HCHO}$ and $\mathrm{CO}$ at the KCMP tall tower, estimated as described in the text. Left panel: monthly mean production rates of $\mathrm{HCHO}$ and $\mathrm{CO}$ calculated from observed methanol concentrations at the KCMP tall tower (blue) compared to the total production rates of HCHO (black) and CO (red) simulated by GEOS-Chem. Right panel: monthly $\mathrm{CO}$ and $\mathrm{HCHO}$ production rates computed from the methanol measurements at the KCMP tall tower plotted as a fraction of the total production rates simulated by GEOS-Chem. Shaded areas show the $95 \%$ confidence intervals.

We see from Fig. 8 that $P_{\mathrm{HCHO}}$ and $P_{\mathrm{CO}}$ estimated from the methanol observations at the KCMP tall tower range from $1.4 \times 10^{4}$ to $8.1 \times 10^{5}$ molec $\mathrm{cm}^{-3} \mathrm{~s}^{-1}$, with an annual mean of $2.3 \times 10^{5}$ molec $\mathrm{cm}^{-3} \mathrm{~s}^{-1}$. Observed methanol concentrations thus account for between 4 and $25 \%$, and on average $12 \%$, of the total $\mathrm{CO}$ and $\mathrm{HCHO}$ production rates as simulated by the GEOS-Chem model. Methanol's contribution in late summer $(\sim 12 \%)$ is comparable to that seen at Blodgett Forest Research Station in California (13-18\% during daytime in late summer) (Choi et al., 2010). At the KCMP tall tower, the highest fractional contribution to tropospheric $\mathrm{HCHO}$ and $\mathrm{CO}(\sim 20 \%)$ occurs during April, May, and June, at a time when methanol emissions and concentrations are high, but prior to the seasonal peak in isoprene emissions later in the summer. Thus the seasonal phase shift for methanol compared to isoprene manifests in terms of a pronounced photochemical role early in the growing season. This role is underestimated in the model because the simulated seasonal peak occurs too late in the summer.

\section{Conclusions}

We applied measurements of a suite of atmospheric VOCs and CO over one year (January 2010-February 2011) from the KCMP tall tower in the US Upper Midwest to test our understanding of methanol sources and seasonal impacts as represented in a current chemical transport model.

Measured methanol concentrations at the KCMP tall tower ranged from $0.1 \mathrm{ppbv}$ to $25 \mathrm{ppbv}$ with an annual mean of 
$3.8 \mathrm{ppbv}$. This is at the low end of the sparse measurements previously reported for the US Midwest, and in the range observed at rural sites elsewhere. Methanol concentrations observed at the KCMP tall tower exhibited a strong seasonal pattern driven by biogenic emissions, with concentrations highest during summer and lowest during winter. The seasonality simulated by GEOS-Chem (driven by MEGANv2.0) is generally similar to the observations, but the seasonal peak occurs about 1 month later than is observed. This suggests a model underestimate of the relative methanol emission for younger versus older leaves in this region.

We examined the year-round importance of anthropogenic methanol emissions in the US Upper Midwest using a source tracer approach. This method was first validated by applying it to the GEOS-Chem output and comparing the results to the known anthropogenic methanol in the model, and by employing multiple observed anthropogenic tracers $(\mathrm{CO}$, benzene, and toluene). Anthropogenic methanol sources accounted for approximately $10 \%$ of the total observed abundance during summer, and up to $70 \%$ during winter. We attribute the remainder to predominantly biogenic emissions during summer and to a mixture of sources during winter.

Biogenic methanol emissions increase exponentially with temperature, and an exponential fit of summer daytime methanol concentrations to temperature at the KCMP tall tower yields a regression coefficient of 0.087 (95\% CI: 0.082-0.094), statistically consistent with the value from a corresponding fit using the simulated methanol abundance $(0.083,95 \%$ CI: $0.078-0.088)$. We conclude that the temperature dependence of emissions employed for methanol in MEGANv2.0 is accurate to within the constraints provided by our data. However, the simulated methanol concentrations are biased low by on average $35 \%$ during summer, suggesting that some other emission parameters (such as the base emission factors) are not accurately represented for this region. A small bias (on average $-0.9^{\circ} \mathrm{C}$ ) in the assimilated GEOS-5 temperatures used in GEOS-Chem is insufficient to correct the discrepancy.

Finally, we estimated the $\mathrm{CO}$ and $\mathrm{HCHO}$ production rates from the methanol measurements and evaluated methanol's importance as a precursor of these two key compounds. Observed methanol concentrations accounted for on average $12 \%$ (and between $4 \%$ and $25 \%$ ) of the total $\mathrm{CO}$ and $\mathrm{HCHO}$ production rates as simulated by the GEOS-Chem model, with the highest seasonal contribution (20\%) during spring and early summer. At this time, methanol emissions and concentrations are high, while regional isoprene emissions are still relatively low. The biased seasonality in the model means that the photochemical role of methanol in the early growing season is not adequately accounted for.

The measurements presented here provide new constraints on the seasonality of natural and anthropogenic contributions to atmospheric methanol abundance. We plan in the future to apply these data in a high-resolution inverse analysis to quantify the impact from different plant types on concentrations of methanol and other VOCs for this region. In the GEOSChem simulation, methanol from crops and grasslands account for nearly $80 \%$ of the total abundance at the KCMP tall tower in the summer. Better information on seasonal fluxes from crops and grasslands is thus key to improving simulations of atmospheric composition for the central US.

Acknowledgements. This research is supported by the National Science Foundation (Grant \# 0937004) and by the University of Minnesota. We thank Tom Nelson and Minnesota Public Radio (KCMP 89.3), Nicholas Boeke, Brandy Toner, as well as Matt Erickson and the rest of the UMN biometeorology group (www.biometeorology.umn.edu) for their help throughout this study. We also thank Joost de Gouw and Carsten Warneke for their generous assistance and suggestions. This work was carried out in part using computing resources at the University of Minnesota Supercomputing Institute.

Edited by: R. Holzinger

\section{References}

Andreae, M.O. and Merlet, P.: Emission of trace gases and aerosols from biomass burning, Global Biogeochem. Cy., 15, 955-966, doi:10.1029/2000GB001382, 2001.

Atkinson, R., Baulch, D. L., Cox, R. A., Crowley, J. N., Hampson, R. F., Hynes, R. G., Jenkin, M. E., Rossi, M. J., Troe, J., and IUPAC Subcommittee: Evaluated kinetic and photochemical data for atmospheric chemistry: Volume II. Gas phase reactions of organic species, Atmos. Chem. Phys., 6, 3625-4055, doi:10.5194/acp-6-3625-2006, 2006.

Bey, I., Jacob, D. J., Yantosca, R. M., Logan, J. A., Field, B. D., Fiore, A. M., Li, Q. B., Liu, H. G. Y., Mickley, L. J., and Schultz, M. G.: Global modeling of tropospheric chemistry with assimilated meteorology: Model description and evaluation, J. Geophys. Res., 106, 23073-23095, 2001.

Choi, W., Faloona, I. C., Bouvier-Brown, N. C., McKay, M., Goldstein, A. H., Mao, J., Brune, W. H., LaFranchi, B. W., Cohen, R. C., Wolfe, G. M., Thornton, J. A., Sonnenfroh, D. M., and Millet, D. B.: Observations of elevated formaldehyde over a forest canopy suggest missing sources from rapid oxidation of arboreal hydrocarbons, Atmos. Chem. Phys., 10, 8761-8781, doi:10.5194/acp-10-8761-2010, 2010.

Corcoran, J. M.: Assessing the spatial variability of net ecosystem carbon dioxide production in the Upper Midwest, M. S. thesis, University of Minnesota-Twin Cities, US, 123 pp., 2009.

de Gouw, J. A. and Warneke, C.: Measurements of volatile organic compounds in the Earth's atmosphere using proton-transferreaction mass spectrometry, Mass Spectrom. Rev., 26, 223-257, doi:10.1002/mas.20119, 2007.

de Gouw, J. A., Goldan, P. D., Warneke, C., Kuster, W. C., Roberts, J. M., Marchewka, M., Bertman, S. B., Pszenny, A. A. P., and Keene, W. C.: Validation of proton transfer reaction-mass spectrometry (PTR-MS) measurements of gas-phase organic compounds in the atmosphere during the New England Air Quality Study (NEAQS) in 2002, J. Geophys. Res., 108, 4682, doi:10.1029/2003JD003863, 2003.

de Gouw, J. A., Middlebrook, A. M., Warneke, C., Goldan, P. D., Kuster, W. C., Roberts, J. M., Fehsenfeld, F. C., Worsnop, 
D. R., Canagaratna, M. R., Pszenny, A. A. P., Keene, W. C., Marchewka, M., Bertman, S. B., and Bates, T.S.: Budget of organic carbon in a polluted atmosphere: Results from the New England Air Quality Study in 2002, J. Geophys. Res., 110, D16305, doi:10.1029/2004JD005623, 2005.

Dufour, G., Szopa, S., Barkley, M. P., Boone, C. D., Perrin, A., Palmer, P. I., and Bernath, P. F.: Global uppertropospheric formaldehyde: Seasonal cycles observed by the ACE-FTS satellite instrument, Atmos. Chem. Phys., 9, 38933910, doi:10.5194/acp-9-3893-2009, 2009.

Duncan, B. N., Logan, J. A., Bey, I., Megretskaia, I. A., Yantosca, R. M., Novelli, P. C., Jones, N. B., and Rinsland, C. P.: Global budget of CO, 1988-1997: Source estimates and validation with a global model, J. Geophys. Res., 112, D22301, doi:10.1029/2007JD008459, 2007.

EPA: Environmental Protection Agency National Emission Inventory for 1999: http://www.epa.gov/ttnchie1/net/1999inventory. html, last access: 1 March 2011, 1999.

Fall, R.: Abundant oxygenates in the atmosphere: A biochemical perspective, Chem. Rev., 103, 4941-4951, doi:10.1021/cr0206521, 2003.

Fall, R. and Benson, A. A.: Leaf methanol - the simplest natural product from plants, Trends Plant Sci., 1, 296-301, doi:10.1016/S1360-1385(96)88175-0, 1996.

Folkers, A., Huve, K., Ammann, C., Dindorf, T., Kesselmeier, J., Kleist, E., Kuhn, U., Uerlings, R., and Wildt, J.: Methanol emissions from deciduous tree species: Dependence on temperature and light intensity, Plant Biol., 10, 65-75, doi:10.1111/j.14388677.2007.00012.x, 2008.

Galbally, I. E. and Kirstine, W.: The production of methanol by flowering plants and the global cycle of methanol, J. Atmos. Chem., 43, 195-229, doi:10.1023/A:1020684815474, 2002.

Goldan, P. D., Trainer, M., Kuster, W. C., Parrish, D. D., Carpenter, J., Roberts, J. M., Yee, J. E., and Fehsenfeld, F. C.: Measurements of hydrocarbons, oxygenated hydrocarbons, carbon monoxide, and nitrogen oxides in an urban basin in Colorado: Implications for emission inventories, J. Geophys. Res., 100, 22771-22783, 1995.

Griffis, T. J., Baker, J. M., Sargent, S. D., Eriksson, M., Corcoran, J., Chen, M., and Billmark, K.: Influence of $\mathrm{C}_{4}$ vegetation on ${ }^{13} \mathrm{CO}_{2}$ discrimination and isoforcing in the Upper Midwest, United States, Global Biogeochem. Cy., 24, GB4006, doi:10.1029/2009GB003768, 2010.

Guenther, A., Karl, T., Harley, P., Wiedinmyer, C., Palmer, P. I., and Geron, C.: Estimates of global terrestrial isoprene emissions using MEGAN (Model of Emissions of Gases and Aerosols from Nature), Atmos. Chem. Phys., 6, 3181-3210, doi:10.5194/acp-63181-2006, 2006.

Harley, P., Greenberg, J., Niinemets, Ü., and Guenther, A.: Environmental controls over methanol emission from leaves, Biogeosciences, 4, 1083-1099, doi:10.5194/bg-4-1083-2007, 2007.

Heikes, B. G., Chang, W. N., Pilson, M. E. Q., Swift, E., Singh, H. B., Guenther, A., Jacob, D. J., Field, B. D., Fall, R., Riemer, D., and Brand, L.: Atmospheric methanol budget and ocean implication, Global Biogeochem. Cy., 16, 1133, doi:10.1029/2002GB001895, 2002.

Holzinger, R., Warneke, C., Hansel, A., Jordan, A., Lindinger, W., Scharffe, D.H., Schade, G., and Crutzen, P. J.: Biomass burning as a source of formaldehyde, acetaldehyde, methanol, ace- tone, acetonitrile, and hydrogen cyanide, Geophys. Res. Lett., 26, 1161-1164, doi:10.1029/1999GL900156, 1999.

Hudman, R. C., Jacob, D. J., Turquety, S., Leibensperger, E. M., Murray, L. T., Wu, S., Gilliland, A. B., Avery, M., Bertram, T. H., Brune, W., Cohen, R. C., Dibb, J. E., Flocke, F. M., Fried, A., Holloway, J., Neuman, J. A., Orville, R., Perring, A., Ren, X., Sachse, G. W., Singh, H. B., Swanson, A., and Wooldridge, P. J.: Surface and lightning sources of nitrogen oxides over the United States: Magnitudes, chemical evolution, and outflow, J. Geophys. Res., 112, D12S05, doi:10.1029/2006JD007912, 2007.

Hudman, R. C., Murray, L. T., Jacob, D. J., Millet, D. B., Turquety, S., Wu, S., Blake, D. R., Goldstein, A. H., Holloway, J., and Sachse, G. W.: Biogenic versus anthropogenic sources of CO in the United States, Geophys. Res. Lett., 35, L04801, doi:10.1029/2007GL032393, 2008.

Jacob, D. J., Field, B. D., Li, Q. B., Blake, D. R., de Gouw, J., Warneke, C., Hansel, A., Wisthaler, A., Singh, H. B., and Guenther, A.: Global budget of methanol: Constraints from atmospheric observations, J. Geophys. Res., 110, D08303, doi:10.1029/2004JD005172, 2005.

Jordan, C., Fitz, E., Hagan, T., Sive, B., Frinak, E., Haase, K., Cottrell, L., Buckley, S., and Talbot, R.: Long-term study of VOCs measured with PTR-MS at a rural site in New Hampshire with urban influences, Atmos. Chem. Phys., 9, 4677-4697, doi:10.5194/acp-9-4677-2009, 2009.

Karl, T., Guenther, A., Spirig, C., Hansel, A., and Fall, R.: Seasonal variation of biogenic VOC emissions above a mixed hardwood forest in northern Michigan, Geophys. Res. Lett., 30, 2186 , doi:10.1029/2003GL018432, 2003.

Karl, T., Harley, P., Emmons, L., Thornton, B., Guenther, A., Basu, C., Turnipseed, A., and Jardine, K.: Efficient atmospheric cleansing of oxidized organic trace gases by vegetation, Science, 330 , 816-819, doi:10.1126/science.1192534, 2010.

Lappalainen, H. K., Sevanto, S., Bäck, J., Ruuskanen, T. M., Kolari, P., Taipale, R., Rinne, J., Kulmala, M., and Hari, P.: Day-time concentrations of biogenic volatile organic compounds in a boreal forest canopy and their relation to environmental and biological factors, Atmos. Chem. Phys., 9, 5447-5459, doi:10.5194/acp-9-5447-2009, 2009.

Legreid, G., Loov, J. B., Staehelin, J., Hueglin, C., Hill, M., Buchmann, B., Prevot, A. S. H., and Reimann, S.: Oxygenated volatile organic compounds (OVOCs) at an urban background site in Zurich (Europe): Seasonal variation and source allocation, Atmos. Environ., 41, 8409-8423, doi:10.1016/j.atmosenv.2007.07.026, 2007.

Lindinger, W., Hansel, A., and Jordan, A.: On-line monitoring of volatile organic compounds at pptv levels by means of ProtonTransfer-Reaction Mass Spectrometry (PTR-MS)- Medical applications, food control and environmental research, Int. J. Mass Spectrom., 173, 191-241, doi:10.1016/S0168-1176(97)00281-4, 1998.

MacDonald, R.C. and Fall, R.: Detection of substantial emissions of methanol from plants to the atmosphere, Atmos. Environ., 27, 1709-1713, doi:10.1016/0960-1686(93)90233-O, 1993.

Madronich, S. and Calvert, J. G.: Permutation reactions of organic peroxy radicals in the troposphere, J. Geophys. Res., 95, 56975715, 1990.

Millet, D. B., Goldstein, A. H., Allan, J. D., Bates, T. S., Boudries, H., Bower, K. N., Coe, H., Ma, Y. L., McKay, M., Quinn, P. 
K., Sullivan, A., Weber, R. J., and Worsnop, D. R.: Volatile organic compound measurements at Trinidad Head, California, during ITCT 2K2: Analysis of sources, atmospheric composition, and aerosol residence times, J. Geophys. Res., 109, D23S16, doi:10.1029/2003JD004026, 2004.

Millet, D. B., Donahue, N. M., Pandis, S. N., Polidori, A., Stanier, C. O., Turpin, B. J., and Goldstein, A. H.: Atmospheric volatile organic compound measurements during the Pittsburgh Air Quality Study: Results, interpretation, and quantification of primary and secondary contributions, J. Geophys. Res., 110, D07S07, doi:10.1029/2004JD004601, 2005.

Millet, D. B., Jacob, D. J., Turquety, S., Hudman, R. C., Wu, S. L., Fried, A., Walega, J., Heikes, B. G., Blake, D. R., Singh, H. B., Anderson, B. E., and Clarke, A. D.: Formaldehyde distribution over North America: Implications for satellite retrievals of formaldehyde columns and isoprene emission, J. Geophys. Res., 111, D24S02, doi:10.1029/2005JD006853, 2006.

Millet, D. B., Jacob, D. J., Custer, T. G., de Gouw, J. A., Goldstein, A. H., Karl, T., Singh, H. B., Sive, B. C., Talbot, R. W., Warneke, C., and Williams, J.: New constraints on terrestrial and oceanic sources of atmospheric methanol, Atmos. Chem. Phys., 8, 68876905, doi:10.5194/acp-8-6887-2008, 2008.

Millet, D. B., Guenther, A., Siegel, D. A., Nelson, N. B., Singh, H. B., de Gouw, J. A., Warneke, C., Williams, J., Eerdekens, G., Sinha, V., Karl, T., Flocke, F., Apel, E., Riemer, D. D., Palmer, P. I., and Barkley, M.: Global atmospheric budget of acetaldehyde: 3-D model analysis and constraints from in-situ and satellite observations, Atmos. Chem. Phys., 10, 3405-3425, doi:10.5194/acp-10-3405-2010, 2010.

NOAA-MRCC: National Oceanic and Atmospheric Administration Midwestern Regional Climate Center, http://mrcc.isws.illinois. edu/index.jsp, last access: 1 March 2011.

Riemer, D., Pos, W., Milne, P., Farmer, C., Zika, R., Apel, E., Olszyna, K., Kliendienst, T., Lonneman, W., Bertman, S., Shepson, P., and Starn, T.: Observations of nonmethane hydrocarbons and oxygenated volatile organic compounds at a rural site in the southeastern United States, J. Geophys. Res., 103, 28111-28128, 1998.

Salisbury, G., Williams, J., Holzinger, R., Gros, V., Mihalopoulos, N., Vrekoussis, M., Sarda-Estève, R., Berresheim, H., von Kuhlmann, R., Lawrence, M., and Lelieveld, J.: Ground-based PTR-MS measurements of reactive organic compounds during the MINOS campaign in Crete, July-August 2001, Atmos. Chem. Phys., 3, 925-940, doi:10.5194/acp-3-925-2003, 2003.

Schade, G. W. and Goldstein, A. H.: Seasonal measurements of acetone and methanol: Abundances and implications for atmospheric budgets, Global Biogeochem. Cy., 20, GB1011, doi:10.1029/2005GB002566, 2006.

Schnitzhofer, R., Wisthaler, A., and Hansel, A.: Real-time profiling of organic trace gases in the planetary boundary layer by PTRMS using a tethered balloon, Atmos. Meas. Tech., 2, 773-777, doi:10.5194/amt-2-773-2009, 2009.

Singh, H. B., Kanakidou, M., Crutzen, P. J., and Jacob, D. J.: High concentrations and photochemical fate of oxygenated hydrocarbons in the global troposphere, Nature, 378, 50-54, doi:10.1038/378050A0, 1995.
Singh, H. B., Chen, Y., Tabazadeh, A., Fukui, Y., Bey, I., Yantosca, R., Jacob, D., Arnold, F., Wohlfrom, K., Atlas, E., Flocke, F., Blake, D., Blake, N., Heikes, B., Snow, J., Talbot, R., Gregory, G., Sachse, G., Vay, S., and Kondo, Y.: Distribution and fate of selected oxygenated organic species in the troposphere and lower stratosphere over the Atlantic, J. Geophys. Res., 105, 3795-3805, doi:10.1029/1999JD900779, 2000.

Singh, H. B., Salas, L. J., Chatfield, R. B., Czech, E., Fried, A., Walega, J., Evans, M. J., Field, B. D., Jacob, D. J., Blake, D., Heikes, B., Talbot, R., Sachse, G., Crawford, J. H., Avery, M. A., Sandholm, S., and Fuelberg, H.: Analysis of the atmospheric distribution, sources, and sinks of oxygenated volatile organic chemicals based on measurements over the Pacific during TRACE-P, J. Geophys. Res., 109, D15S07, doi:10.1029/2003JD003883, 2004.

Stavrakou, T., Guenther, A., Razavi, A., Clarisse, L., Clerbaux, C., Coheur, P.-F., Hurtmans, D., Karagulian, F., De Mazière, M., Vigouroux, C., Amelynck, C., Schoon, N., Laffineur, Q., Heinesch, B., Aubinet, M., Rinsland, C., and Müller, J.-F.: First space-based derivation of the global atmospheric methanol emission fluxes, Atmos. Chem. Phys., 11, 4873-4898, doi:10.5194/acp-11-4873-2011, 2011.

Tie, X., Guenther, A., and Holland, E.: Biogenic methanol and its impacts on tropospheric oxidants, Geophys. Res. Lett., 30, 1881, doi:10.1029/2003GL017167, 2003.

Tyndall, G .S., Cox, R. A., Granier, C., Lesclaux, R., Moortgat, G. K., Pilling, M. J., Ravishankara, A. R., and Wallington, T. J.: Atmospheric chemistry of small organic peroxy radicals, J. Geophys. Res., 106, 12157-12182, 2001.

van der Werf, G. R., Randerson, J. T., Giglio, L., Collatz, G. J., Kasibhatla, P. S., and Arellano Jr., A. F.: Interannual variability in global biomass burning emissions from 1997 to 2004, Atmos. Chem. Phys., 6, 3423-3441, doi:10.5194/acp-6-3423-2006, 2006.

Warneke, C., Karl, T., Judmaier, H., Hansel, A., Jordan, A., Lindinger, W., and Crutzen, P.J.: Acetone, methanol, and other partially oxidized volatile organic emissions from dead plant matter by abiological processes: Significance for atmospheric $\mathrm{HO}_{\mathrm{x}}$ chemistry, Global Biogeochem. Cy., 13, 9-17, doi:10.1029/98GB02428, 1999.

Warneke, C., McKeen, S. A., de Gouw, J. A., Goldan, P. D., Kuster, W. C., Holloway, J. S., Williams, E. J., Lerner, B. M., Parrish, D. D., Trainer, M., Fehsenfeld, F. C., Kato, S., Atlas, E. L., Baker, A., and Blake, D. R.: Determination of urban volatile organic compound emission ratios and comparison with an emissions database, J. Geophys. Res., 112, D10S47, doi:10.1029/2006JD007930, 2007.

Williams, J., Holzinger, R., Gros, V., Xu, X., Atlas, E., and Wallace, D. W. R.: Measurements of organic species in air and seawater from the tropical Atlantic, Geophys. Res. Lett., 31, L23S06, doi:10.1029/2004GL020012, 2004. 